\title{
The Effect of Dietary Pioglitazone Supplementation On Milk Yield, Insulin Sensitivity And GH-IGF-I Axis In Holstein Dairy Cows During Transition Period
}

\section{Saeed Mirzaie}

University of Zanjan

Ali Reza Yousefi ( $\nabla$ rezayousefi2005@gmail.com )

Razi Vaccine and Serum Research Institute

Reza Masoumi

University of Zanjan

Behnam Rostami

University of Zanjan

Hamid Amanlou

University of Zanjan

\section{Research Article}

Keywords: dairy cow, IGF-I, insulin sensitivity, thiazolidinedione, transition period.

Posted Date: January 17th, 2022

DOI: https://doi.org/10.21203/rs.3.rs-1147793/v1

License: (9) This work is licensed under a Creative Commons Attribution 4.0 International License.

Read Full License 


\section{Abstract}

High-yielding dairy cows develop insulin resistance during the late gestation, which eventually disrupts the GH-IGF-I axis and cause metabolic and reproductive disorders. The objective of this research was to determine the effects of dietary pioglitazone (PIO) supplementation, as an insulin sensitizer agent, on milk yield, plasma metabolite status and GH-IGF-I axis in transitional Holstein dairy cows. Two experimental groups of twenty multiparous cows were randomly assigned (10 animals/group) and either fed by basal diet (control) or fed by the basal diet supplemented with $6 \mathrm{mg} \mathrm{PIO} / \mathrm{kg}$ body weight (BW) from $\mathrm{d} 14$ before parturition to $\mathrm{d} 21$ postpartum. The BW and body condition score (BCS), and nonesterified fatty acids (NEFA), beta-hydroxybutyrate (BHBA), insulin, glucose, GH, and IGF-I concentrations were measured, weekly. Milk production and composition were also measured weekly during the postpartum period. The BW and BCS losses were lower in PIO cows than the control $(\mathrm{P}<0.05)$. The percentage and amount of milk fat were decreased and the amount of protein increased only in the first week after calving in the PIO-treated cows compared to the control $(\mathrm{P}<0.05)$. Dietary PIO supplementation increased glucose at calving and insulin concentration at calving and in the first week after calving compared to the control $(P<0.05)$. Plasma concentrations of IGF-I and the ratio of IGF to $\mathrm{GH}$ was increased in PIO group $(\mathrm{P}<0.05)$. The mean RQUICKI-BHBA, as insulin sensitivity index, was greater in PIOsupplemented cows $(P<0.05)$. The findings of current study revealed the beneficial effect of PIO supplementation on improving insulin sensitivity and also the GH-IGF-I axis. Dietary PIO feeding may assist in a lower negative energy balance (NEB) and better metabolic and health status in transition dairy cows.

\section{Introduction}

High-yielding dairy cows experience a drastic increment in energy requirements to supply milk production and fetus growth, during the transition period. The increased energy requirements along with a decline in feed intake cause different levels of negative energy balance (NEB) (Butler 1998). Due to genetic selection for higher milk production, the high-yielding dairy cows are more prone to intense NEB and lower peripheral insulin concentration (Bonczek et al. 1988). At this circumference, the decreased glucose uptake by insulin-dependent peripheral tissue helps to drive more glucose toward the mammary gland, as an insulin-independent tissue (Butler et al. 2003). Besides, in line with normal homoerotic changes, the transition dairy cows are exposed to various levels of insulin resistance which would stimulate mobilization of body lipid reserves to mitigate the negative consequences of NEB. Meanwhile, the intensiveness of insulin resistance in the high-producing dairy cows is associated with different metabolic and reproductive disorders.

Insulin is a crucial metabolic key factor/hormone in coupling the GH -IGF axis and hypoinsulinemia and/or insulin resistance down-regulates growth hormone receptors 1A (GHR1A) in the liver, which in turn disrupts the GH- IGF axis (Butler et al. 2003). Decreased GHR1A reduces hepatic and circulatory insulinlike growth factor-I (IGF-I) production, and may reduce the effect of negative feedback on GH secretion and increase the concentration of GH secretion (Lucy 2004). An increment of the GH concentration 
enhances hepatic gluconeogenesis and accelerates lipolysis in adipose tissue, which in turn increases the non-esterified fatty acids (NEFA) concentration (Lucy 2004; Yousefi et al. 2016). In a vicious circle, physiological conditions associated with excessive lipolysis increase insulin resistance causing susceptibility of dairy cows to metabolic and reproductive disorders (Drackley 1999; Duffield 2000).

To date, several strategies such as pharmacological methods including thiazolidinediones (TZD) (Smith et al. 2007; Smith et al. 2009) and insulin (Butler et al. 2003) administration, as well as oral compounds such as anti-lipolytic vitamin (Pires et al. 2007; Pescara et al. 2010) and unsaturated fatty acids (Mashek et al. 2002) have been recommended to encounter insulin resistance and excessive lipolysis in postpartum cows. However, no clear physiological regulator has been identified for the efficacy of oral compounds on mitigating insulin resistance. The TZD family is the most powerful peroxisome proliferator-activated receptors (PPARs) ligand that by activation of their receptors, induces differentiates in adipose tissue, promotes the secretion of insulin, and decreases the release of FFAs from adipose tissue, which eventually influence the intensity of insulin sensitivity (Houseknecht et al. 2002). In the TZD class, pioglitazone (PIO) is a synthetic and specific drug of PPAR-y that its effects on improving fat metabolism, folliculogenesis, and reproductive function have been documented (Yousefi et al. 2016). However, the impact of PIO administration, as an anti-diabetic drug, on recoupling of GH-IGF-I axis in postpartum dairy cows has not been published. The goal of this study was to explore the impacts of PIO supplementation during the transition period on milk yield and components, GH-IGF-I axis status, blood metabolites, hormones, and sensitivity to insulin in dairy cows.

\section{Materials And Methods}

\section{Animals and treatments}

Twenty multiparous (2-4 parity) Holstein dairy cows with no history of severe clinical disease were randomly allotted to two experiment groups from two weeks before to four weeks after parturition. The cows received standard basal diets (Table 1 ) to meet their nutritional requirements during the pre- and postpartum period according to NRC (2001). 
Table 1

Ingredients and nutrient content of dairy cows' diets in the pre- and post-calving period (DM basis)

\begin{tabular}{|c|c|c|}
\hline Item & Pre-calving diet & Post-calving diet \\
\hline \multicolumn{3}{|l|}{ Ingredients (\% of DM) } \\
\hline Alfalfa hay & 21.03 & 12.66 \\
\hline Corn silage & 27.26 & 19.10 \\
\hline Wheat straw & 9.71 & 1.79 \\
\hline Barley grain & 8.23 & 7.08 \\
\hline Corn grain & 17.14 & 15.85 \\
\hline Cottonseed meal & - & 4.81 \\
\hline Soybean meal & 10.40 & 12.52 \\
\hline Soybean, whole- roasted & - & 8.05 \\
\hline Beet pulp & - & 5.49 \\
\hline Wheat bran & 3.47 & 1.79 \\
\hline Corn germ meal & - & 6.95 \\
\hline Meat meal & - & 0.39 \\
\hline Fat powder & - & 0.40 \\
\hline Limestone & - & 0.59 \\
\hline Magnesium oxide & 0.3 & 0.16 \\
\hline Common salt & 0.08 & 0.40 \\
\hline Sodium bicarbonate & - & 0.80 \\
\hline Vitamin and mineral premix* & 2.38 & 1.19 \\
\hline \multicolumn{3}{|l|}{ Nutrient content } \\
\hline $\mathrm{DM}, \%$ & 52.48 & 60.13 \\
\hline NEL (Mcal/kg DM) & 1.54 & 1.66 \\
\hline Ether extract, \% & 2.76 & 5.07 \\
\hline CP, \% & 14.80 & 17.79 \\
\hline
\end{tabular}

*Contained (per $\mathrm{kg}$ ): $16,000,000$ IU vitamin $\mathrm{A} ; 3,200,000$ IU vitamin $\mathrm{D} ; 48,000$ IU vitamin E; $24.0 \mathrm{~g} \mathrm{Fe}$; $24.0 \mathrm{~g} \mathrm{Mn} ; 24.0 \mathrm{~g} \mathrm{Zn;} 12.8 \mathrm{~g} \mathrm{Cu} ; 0.32 \mathrm{~g} \mathrm{Se} 1.44 \mathrm{~g} \mathrm{I} ;$; and $0.32 \mathrm{~g}$ Co.

$\mathrm{DM}$, dry matter; NEl, net energy lactation; $\mathrm{CP}$, crude protein; $\mathrm{ADF}$, acid detergent fiber; NDF, neutral detergent fiber. 


\begin{tabular}{|c|c|c|}
\hline Item & Pre-calving diet & Post-calving diet \\
\hline$A D F, \%$ & 22.60 & 17.60 \\
\hline$N D F, \%$ & 37.00 & 30.5 \\
\hline \multicolumn{3}{|c|}{$\begin{array}{l}\text { *Contained (per kg): } 16,000,000 \mathrm{lU} \text { vitamin A; } 3,200,000 \text { IU vitamin D; } 48,000 \text { IU vitamin E; } 24.0 \mathrm{~g} \mathrm{Fe} \\
24.0 \mathrm{~g} \mathrm{Mn} ; 24.0 \mathrm{~g} \mathrm{Zn;} 12.8 \mathrm{~g} \mathrm{Cu} ; 0.32 \mathrm{~g} \text { Se } 1.44 \mathrm{~g} \mathrm{I} ; \text {; and } 0.32 \mathrm{~g} \mathrm{Co.}\end{array}$} \\
\hline
\end{tabular}

Cows allocation to the experimental groups were balanced based on their previous 305-d matureequivalent milk yield, body condition score (BCS), and parity, and were group-housed in shaded outdoor pens. Treatments were basal diets either supplemented with $6 \mathrm{mg} \mathrm{PIO} / \mathrm{kg} \mathrm{BW/d}$ or without PIO supplementation as the control group (Yousefi et al. 2015; Yousefi et al. 2019). Pioglitazone was provided from Hetero Drugs (India; Batch No: PHD 0510001) as pioglitazone hydrochloride. During the pre- and postpartum periods, cows fed a total mixed ration (TMR) twice a day (0800 and 1600 hours) for ad libitum.

\section{Production Performance}

Body weight and BCS were recorded weekly. Body condition score assessment was performed using three experts using a 5-point scale, and the average of the values was used to determine BCS for each cow (Wildman et al. 1982). Cows were milked three times a day, at 8:00, 16:00, and 24:00. Individual cows' milk production was measured for each milking time until 21 days postpartum. Weekly milk samples were collected from all three consecutive daily milking and stored in plastic tubes containing potassium dichromate at $4^{\circ} \mathrm{C}$. Milk samples were tested using MilkoScan (134 BN Foss Electric, Hillerød, Denmark) for fat, protein, lactose, and total solids. The daily milk yield record was analyzed to calculate the milk composition.

\section{Plasma Metabolites And Hormone Assays}

Blood samples were obtained from the coccygeal vein of all cows on days $-14,-7,0,7,14$, and 21 relatives to calving using evacuated glass tubes containing EDTA (10.5 mg, Monoject; Sherwood Medical, St. Louis, MO, USA(. The collected blood samples were kept at $4^{\circ} \mathrm{C}$, and within $1 \mathrm{~h}$ after sampling centrifuged at $3000 \times \mathrm{g}$ for $10 \mathrm{~min}$. The harvested plasma was stored at $-8^{\circ} \mathrm{C}$ for follow-up examinations. Plasma concentration of glucose (ParsAzmoon Co., Tehran, Iran), non-esterified fatty acids (NEFA) and beta-hydroxybutyrate (Randox Laboratories Ltd., London, UK) were assessed using commercial kits according to the manufacture's procedures. The NEFA and BHBA inter-assay coefficients were 6.1 and $4.4 \%$, while their intra-assay coefficients were 4.3 and $3.9 \%$, respectively. Blood concentrations of insulin (Diaplus Inc., USA), growth hormone (Monobind Inc Lake Forest, CA, USA), and IGF-1 (Hangzhou 
Eastbiopharm Co., Ltd., USA) were measured using ELISA kits according to the manufacturer's instructions. Inter-assay and intra-assay coefficients of variation for insulin assay were 7.5 and $5.4 \%$.

\section{Estimation Of Insulin Sensitivity Index}

In this experiment, the revised quantitative insulin sensitivity check index including BHB (RQUICKI-BHB) were used to determine insulin sensitivity according to the following formula (Balogh et al. 2008):

RQUICKI -BHB $=1 /[\log ($ glucose $(\mathrm{mg} / \mathrm{dL}))+\log ($ insulin $(\mu \mathrm{U} / \mathrm{mL}))+\log (\mathrm{NEFA}(\mathrm{mmol} / \mathrm{L}))+\log (\mathrm{BHB}$ $((\mathrm{mmol} / \mathrm{L}))]$.

\section{Statistical analysis}

The data generated during time (hormones, blood metabolites, BW, BCS) were analyzed using SAS version 9.2 software and MIXED procedure in a complete randomized block design based on parity with time as the repeated measure. BW and BCS were analyzed by GLM procedure. Pretreatment measurements were used as covariates for the respective response variables. Significant differences and tendencies were declared at $P<0.05$ and $0.05 \leq P<0.10$, respectively. The mathematical model was as follows:

$$
\mathrm{Y}_{\mathrm{ijk}}=\mu+\mathrm{T}_{\mathrm{i}}+\mathrm{P}_{\mathrm{j}}+\mathrm{BW}(\mathrm{Xi}-\bar{X})_{i \mathrm{j}}+\mathrm{t}_{\mathrm{i}}+(\mathrm{T} \times \mathrm{t})_{\mathrm{ij} \mathrm{k}}+\delta(\mathrm{T})_{\mathrm{m}}++\mathrm{e}_{\mathrm{ijk}}
$$

Where $Y_{i j k}=$ dependent variable; $\mu$ = population mean; $T_{i}=$ fixed effect of treatment; $P_{j}=$ effect of parity $j ;$

$\mathrm{BW}(\mathrm{Xi}-\bar{X})_{\mathrm{ij}}=$ covariate (body weight); $\mathrm{t}_{\mathrm{j}}=$ is fixed effect of sampling time $\mathrm{j} ;(\mathrm{T} \times \mathrm{t})_{\mathrm{ij}}=$ two-way interaction of treatment $\mathrm{i}$ by sampling time $\mathrm{j} ; \delta(T)_{\mathrm{ik}}=$ random effect of cow $\mathrm{k}$ nested within treatment $\mathrm{l} ; \mathrm{e}_{\mathrm{ijk}}=$ residual random error.

\section{Results}

The effects of PIO on BW and BCS are presented in Table 2. The mean of post parturition BW in PIOtreated cows tended to increase compared to the control group $(P=0.06)$. A significant interaction of treatment $\times$ time on BW was detected, where the control cows had lower BW at the second postparturition week (Fig. 1). Also, the control cows lost more BW compared to PIO cows during postpartum period $(P<0.05)$. Although BCS was not affected by feeding PIO, it caused lower BCS loss in PIO-treated cows compared to control cows $(P<0.05)$. 
Table 2

The effect of Pioglitazone feeding on mean body weight and body condition score of Holstein dairy cows ( $n=10$ cows per treatment)

\begin{tabular}{|llllllll|}
\hline Item & \multicolumn{3}{l}{ Treatments $^{*}$} & SEM & \multicolumn{2}{l|}{ P value } \\
\cline { 2 - 3 } & Control & PIO & & Treatment & Time & Treatment $\times$ time \\
\hline BW $(\mathrm{kg})$ & 643.81 & 666.47 & 8.66 & 0.06 & $<0.01$ & 0.04 \\
\hline BW loss $(\mathrm{kg})$ & $33.01^{\mathrm{b}}$ & $24.28^{\mathrm{a}}$ & 1.91 & $<0.01$ & - & - \\
\hline BCS $^{\dagger}$ & 3.34 & 3.58 & 0.61 & 0.79 & 0.39 & 0.26 \\
\hline BCS loss & $0.98^{\text {a }}$ & $0.73^{\mathrm{b}}$ & 0.05 & $<0.01$ & - & - \\
\hline a,b Within the same row, values with different superscripts are significantly different $(\mathrm{P}<0.05)$.
\end{tabular}

Note:

*Animals either fed by basal diet (control) or fed by the basal diet supplemented with $6 \mathrm{mg} \mathrm{PIO} / \mathrm{kg}$ body weight (PIO) from d 14 before parturition to $\mathrm{d} 21$ postpartum. BW and BW loss were measured during the postpartum period; while BCS was measured from 14 days before to 21 days after calving.

The effects of PIO supplementation on milk yield and composition are shown in Table 3. Results showed that milk production was not affected by the treatments. However, the percentage $(P<0.05)$ and amount of milk fat $(P \leq 0.08)$ in the PIO-treated cows were decreased as compared to the control cows. The significant interaction of treatment $\times$ time on the percentage and production of milk protein (Fig. 2) revealed that PIO supplementation increased milk protein during the first week of lactation in PIO cows than the control cows $(\mathrm{P}<0.05)$. However, $\mathrm{PIO}$ supplementation had no significant effect on the total milk protein, lactose, and solids. 
Table 3

The effect of Pioglitazone feeding on milk production and composition of Holstein dairy cows during postpartum period ( $n=10$ cows per treatment)

\begin{tabular}{|c|c|c|c|c|c|c|}
\hline \multirow[t]{2}{*}{ Item } & \multicolumn{2}{|c|}{ Treatments* } & \multirow[t]{2}{*}{ SEM } & \multicolumn{3}{|l|}{$P$ value } \\
\hline & Control & PIO & & Treatment & Time & Treatment $\times$ time \\
\hline Milk yield, kg/d & 40.02 & 38.98 & 2.06 & 0.72 & $<0.01$ & 0.63 \\
\hline $4 \% \mathrm{FCM}^{\star \star}, \mathrm{kg} / \mathrm{d}$ & 42.80 & 39.06 & 2.03 & 0.21 & $<0.01$ & 0.91 \\
\hline Fat, \% & $4.48^{\mathrm{a}}$ & $4.05^{b}$ & 0.11 & 0.02 & $<0.01$ & 0.36 \\
\hline Fat, kg/d & 1.77 & 1.56 & 0.05 & 0.08 & 0.02 & 0.09 \\
\hline Protein, \% & $3.40^{\mathrm{b}}$ & $3.82^{\mathrm{a}}$ & 0.10 & $<0.01$ & $<0.01$ & 0.01 \\
\hline Protein, kg/d & 1.35 & 1.47 & 0.08 & 0.30 & $<0.01$ & 0.01 \\
\hline Lactose, \% & 4.68 & 4.61 & 0.07 & 0.50 & $<0.01$ & 0.60 \\
\hline Total solids, \% & 12.76 & 12.45 & 0.15 & 0.16 & $<0.01$ & 0.23 \\
\hline Total solids, kg/d & 5.08 & 4.83 & 0.25 & 0.48 & $<0.02$ & 0.66 \\
\hline \multicolumn{7}{|c|}{ a,b Within the same row, values with different superscripts are significantly different $(P<0.05)$. } \\
\hline \multicolumn{7}{|c|}{$\mathrm{PIO}=$ pioglitazone; $\mathrm{SEM}=$ standard error of mean. } \\
\hline \multicolumn{7}{|c|}{$\begin{array}{l}\text { "Animals either fed by basal diet (control) or fed by the basal diet supplemented with } 6 \mathrm{mg} \mathrm{PIO} / \mathrm{kg} \\
\text { body weight (PIO) from d } 14 \text { before parturition to d } 21 \text { postpartum. }\end{array}$} \\
\hline
\end{tabular}

Effect of PIO supplementation on plasma metabolites and hormones are shown in Table 4. Dietary inclusion of PIO decreased plasma concentrations of NEFA and BHBA in PIO-treated compared to the control cows $(P<0.05)$. The interaction of treatment $x$ time on plasma NEFA showed that $P I O$ reduced NEFA concentrations during the first and second postpartum weeks $(P<0.05 ; \mathrm{Fig}$. 3 ). PIO supplementation had no significant effect on plasma concentrations of glucose; however, there was a significant interaction of treatmentx time, where PIO-treated cows had a higher concentration of glucose at calving $(\mathrm{P}<0.05 ;$ Fig. 4). Plasma insulin concentrations were not different in PIO and control cows; however, the significant interaction between treatment $\times$ time on plasma insulin revealed that PIO feeding increased the plasma insulin at calving and at the first post-calving week $(P<0.05$; Fig. 5). 
Table 4

The effect of Pioglitazone feeding on blood metabolites, hormones, and insulin sensitivity index in Holstein dairy cows during transition period ( $n=10$ cows per treatment)

\begin{tabular}{|c|c|c|c|c|c|c|}
\hline \multirow[t]{2}{*}{ Item } & \multicolumn{2}{|c|}{ Treatments $^{*}$} & \multirow[t]{2}{*}{ SEM } & \multicolumn{3}{|l|}{$P$ value } \\
\hline & Control & PIO & & Treatment & Time & Treatment $\times$ time \\
\hline NEFA (mmol/L) & $0.65^{\mathrm{a}}$ & $0.49^{b}$ & 0.04 & $<0.01$ & $<0.01$ & 0.04 \\
\hline BHBA (mmol/L) & $0.70^{\mathrm{a}}$ & $0.48^{b}$ & 0.04 & $<0.01$ & $<0.01$ & 0.15 \\
\hline Glucose (mg/dL) & 57.95 & 59.67 & 1.82 & 0.52 & $<0.01$ & 0.04 \\
\hline Insulin ( $\mu \mathrm{IU} / \mathrm{mL})$ & 9.76 & 10.83 & 0.49 & 0.13 & $<0.01$ & $<0.01$ \\
\hline $\mathrm{GH}(\mu \mathrm{g} / \mathrm{L})$ & 3.37 & 3.23 & 0.28 & 0.74 & $<0.01$ & 0.99 \\
\hline IGF-1 ( $\mu \mathrm{g} / \mathrm{L})$ & $35.12^{b}$ & $49.95^{a}$ & 3.73 & 0.02 & $<0.01$ & 0.97 \\
\hline IGF/GH ratio & $17.96^{\mathrm{b}}$ & $29.61^{a}$ & 4.59 & 0.04 & $<0.01$ & 0.86 \\
\hline IGF/ Insulin ratio & 4.53 & 5.56 & 0.55 & 0.20 & 0.37 & 0.25 \\
\hline RQUICKI-BHBA index ${ }^{* *}$ & $0.46^{\mathrm{b}}$ & $0.50^{\mathrm{a}}$ & 0.01 & 0.03 & $<0.01$ & $<0.01$ \\
\hline \multicolumn{7}{|c|}{ a,b Within the same row, values with different superscripts are significantly different $(P<0.05)$. } \\
\hline \multicolumn{7}{|c|}{$\begin{array}{l}\mathrm{PIO}=\text { pioglitazone; } \mathrm{SEM}=\text { standard error of mean; } \mathrm{NEFA}=\text { non-esterified fatty acids; } \mathrm{BHBA}=\text { beta- } \\
\text { hydroxybutyrate; } \mathrm{GH}=\text { Growth hormone; IGF- } 1=\text { insulin like growth factor- } 1 \text {. }\end{array}$} \\
\hline \multicolumn{7}{|c|}{$\begin{array}{l}\text { *Animals either fed by basal diet (control) or fed by the basal diet supplemented with } 6 \mathrm{mg} \mathrm{PIO} / \mathrm{kg} \\
\text { body weight (PIO) from d } 14 \text { before parturition to d } 21 \text { postpartum. }\end{array}$} \\
\hline \multicolumn{7}{|c|}{$\begin{array}{l}\text { ** RQUICKI-BHBA index = revised quantitative insulin sensitivity check index including BHB, calculated } \\
\text { as: } 1 /[\log (\mathrm{glucose}(\mathrm{mg} / \mathrm{dL}))+\log (\text { insulin }(\mu \mathrm{U} / \mathrm{mL}))+\log (\mathrm{NEFA}(\mathrm{mmol} / \mathrm{L}))+\log (\mathrm{BHB}((\mathrm{mmol} / \mathrm{L}))] \text {. }\end{array}$} \\
\hline
\end{tabular}

Plasma concentration of GH and the ratio of IGF-I to insulin were not influenced by PIO supplementation; meanwhile, the concentration of IGF-I and the ratio of IGF-I to GH was increased in the treatment group compared to the control group $(\mathrm{P}<0.05)$. Moreover, $\mathrm{PIO}$ feeding improved the RQUICKI-BHB index in the treated dairy cows compared to the control cows $(P<0.05)$. There was a significant interaction of treatment $\times$ time on RQUICKI-BHB index, where it was greater in PIO cows than the control cows at $d-7$ and +14 relative to parturition $(P<0.05$; Fig. 6$)$.

\section{Discussion}

The health of dairy cows is endangered by metabolic changes around calving (Ospina et al. 2010; Celi and Gabai 2015). The present study showed that PIO supplementation improved the metabolic parameters and insulin sensitivity index of dairy cows during the transition period. 
Plasma NEFA concentration is a well-known biomarker of lipolysis (Tordjman et al. 2003). Previous studies have indicated that TZD administration reduced the plasma NEFA concentration during the postpartum period (Smith et al. 2007; Smith et al. 2009; Schoenberg and Overton 2011). Ghoreishi (2012) also showed that supplementation of $4 \mathrm{mg} \mathrm{PIO} / \mathrm{kg} \mathrm{BW}$ was able to reduce the concentration of NEFA. It has been suggested that TZD supplements decrease insulin resistance by reducing plasma NEFA in dairy steers (Kushibiki et al. 2001). The effect of PIO supplementation on lowering plasma NEFA concentration is explained by two potential mechanisms including: 1) increasing dry matter intake during the postpartum period (Smith et al. 2007; Smith et al. 2009; Ghoreishi 2012) which mitigated NEB, and 2) reesterification of fatty acids, reducing mobilization, and stimulating liver capacity for free fatty acids oxidation (Tordjman et al. 2003; Yousefi et al. 2016).

In addition to NEFA, BHBA is another metabolite that is associated with energy balance and liver functioning in lactating cows (Ospina et al. 2010). In this study, the decrease in BHBA concentration with PIO intake was consistent with the study of Yousefi et al. (2016), who showed that feeding 6 mg PIO per kg BW decreased plasma BHBA concentration in dairy cows. Smith et al. (2007) also stated that administration of 2 or 4 mg TZD per kg decreased plasma BHBA concentration. Nevertheless, others did not find plasma BHBA changes (Ghoreishi 2012; Gheise et al. 2018) or even observed higher plasma BHBA (Smith et al. 2009) after administration of TZDs in dairy cows. Decreased plasma NEFA availability and increased hepatic capacity for free fatty acids oxidation are the main reasons considered to explain the reduced BHBA in PIO-supplemented cows (Ide et al. 2000; Allen et al. 2005; Yousefi et al. 2016).

In the present study, PIO supplementation had no significant effect on plasma insulin concentration throughout the study; however, it caused higher plasma concentrations during calving and the first week after calving in PIO-treated cows. In agreement with our results, Schoenberg and Overton (2011) reported that TZD did not significantly alter plasma insulin concentrations. Although we did not measure the DMI, increasing dry matter intake has been reported to increase plasma glucose (Wolden-Hanson et al. 2002; Larsen et al. 2003; Smith et al. 2007; Ghoreishi 2012) which in turn can increase the insulin concentration. The results of current study showed that PIO supplementation did not influenced mean plasma glucose concentrations, which was in agreement with the results of Smith et al. (2007) and Ghoreishi (2012); however, the interaction effect of treatment and time on plasma glucose revealed that it was increased at calving in PIO-treated cows. Consistently, some studies have suggested that administration of 2 or $4 \mathrm{mg}$ TZD /BW increased the concentration of glucose during the periparturient period as a result of the increased liver glycogen to triglyceride ratio and hepatic gluconeogenesis (Smith et al. 2009; Schoenberg and Overton 2011).

The PIO supplementation increased the plasma IGF-1 concentration and the IGF-I to GH ratio, but did not affect the GH concentration. Consistent results was reported by Yousefi et al. (2016), but, Gheise et al. (2018) stated that PIO supplementation did not affect IGF-I plasma concentrations, likely due to the use of PIO in short term feeding period (28 days). The high-producing dairy cows experience low plasma IGF1 and high $\mathrm{GH}$ concentrations during the transition period (Lucy 2004). The uncoupling of the somatotropic axis in postpartum cows is probably due to a decrease in hepatic growth hormone receptor 
1A (GHR 1A) during the prepartum period (Lucy 2004). Therefore, increasing the GHR 1A receptor and improving dry matter intake, and reducing the NEB may cause subsequent recoupling of this axis (Butler et al. 2003). In the present study, NEB indices, such as NEFA and BHBA, were significantly decreased. These effects were also supported by the previous findings showing higher dry matter intake and lower NEB during the postpartum in TZD-treated cows (Smith et al. 2007; Smith et al. 2009). It could be postulated that the higher IGF-I concentration per insulin unit in the PIO-supplemented cows is due to the possible improvement in the response of the liver and other peripheral tissues to insulin. Probably, the effect of PIO on increasing liver's sensitivity to insulin and more expression of the GHR 1A receptor resulted in more efficient IGF-1 production in the liver.

The results also showed that PIO supplementation had no effect on milk production, but it did increase the percentage of milk fat. In line with this result, Yousefi et al. (2016) showed that PIO supplementation reduced the milk fat percentage in dairy cows. It has been also shown that administration of $4 \mathrm{mg}$ TZD per kg BW before calving tended to reduce milk fat percentage in dairy cows (Smith et al. 2009). As a component influencing blood fat metabolites and body fat mobilization, it could be postulated that the reduced milk fat is a consequence of lowering blood NEFA and other fat metabolites that are directly involved in the milk fat synthesis (Lucy 2004). On the other hand, TZD administration has shown to alter lipogenic gene networks in bovine mammary epithelial cells (Kadegowda et al. 2009) and therefore could change de novo fat synthesis in mammary glands. The increased percentage of milk protein in the first week after calving by supplementing PIO is probably due to the increased concentration of colostrum and milk immunoglobulins, which occurred following improving the immune function of periparturient cows. This assumption is supported by the results of previous findings where TZD administration improved the immunity of periparturient cows (Revelo and Waldron 2010) and dairy goat (Rosa et al. 2017).

Dietary PIO supplementation reduced BCS and BW loss. Consistent with our findings, it has been reported that cows fed PIO experienced lesser BCS loss during transition period (Smith et al. 2009; Yousefi et al. 2016; Gheise et al. 2018). However, no significant effect of TZD on the reduction of BCS and BW losses also has been reported (Smith et al. 2007; Schoenberg and Overton 2011). The discrepancy between the literature is likely depends on the TZD level, route of administration or duration of administration. Lower concentrations of lipolysis indices (NEFA and BHBA) indicate that PIO supplementation potentially improved the lipid metabolism and thus energy balance. In addition, less energy used to synthesis of milk fat and possibly more energy income (as dry matter) are other reasons for the reduction in BCS and BW loss.

Our findings indicated that PIO supplementation increased insulin sensitivity index. The RQUICKI-BHB index is a significant influencing factor for the relationship between baseline and dynamic glucose, NEFA, BHB, and insulin levels in ketotic cows (Djoković et al. 2017). The revised quantitative insulin sensitivity check Index (RQUICKI) and its modified variant (RQUICKI-BHB) appear to be similarly capable of estimating insulin sensitivity changes (Balogh et al. 2008). The addition of BHB to the RQUICKI index would assist in the evaluation of insulin sensitivity in a quicker and more efficient. Our findings showed that the insulin index increased in PIO- fed cows, which could be due to a decrease in NIFA and BHBA

Page $11 / 21$ 
concentration. Gheise et al. (2018) and Schoenberg et al. (2011) showed that PIO and TZD treatments did not affect RQUICKI index. The RQUICKI has a poor distinguishing capacity when it applies to diagnosing reduced insulin sensitivity in cows, particularly when they are affected by metabolic diseases (Kerestes et al. 2009). Therefore, it can be assumed that the significant effect of PIO supplementation on insulin resistance in our study is due to the use of RQUICKI-BHBA values. In addition, PIO supplementation increased the plasma IGF-1 concentration and the IGF-I to GH ratio, but did not affect the GH concentration. Consistent results were reported by Yousefi et al. (2016), but Gheise et al. (2018) stated that PIO supplementation did not influence IGF-I plasma concentrations, likely due to the use of PIO in the short term feeding period (28 days). The high-producing dairy cows experience low plasma IGF-1 and high $\mathrm{GH}$ concentrations during the transition period (Lucy 2004). The uncoupling of the somatotropic axis in postpartum cows is probably due to a decrease in hepatic GHR 1 A during the prepartum period (Lucy 2004). Therefore, increasing the GHR 1A receptor as a results of lower NEB may involve in recoupling of this axis (Butler et al. 2003).

\section{Conclusion}

Insulin resistance in dairy cows is associated with several metabolic and reproductive disorders. Results of the present study showed that dietary supplementation of PIO improved insulin sensitivity index and IGF-I to GH ratio. Moreover, the findings indicated that PIO supplementation influenced energy output and lipolysis by reducing milk fat, and decreased plasma concentrations of NEFA and BHBA. These observations along with lower BW and BCS loss are emphasized on the mitigating effects of PIO on NEB in dairy cows.

\section{Declarations}

\section{Author contribution}

Saeed Mirzaie \& Ali Reza Yousefi: Conceptualization, Methodology, Supervision, Project administration, Writing - review \& editing. Reza Masoumi, Behnam Rostami \& Hamid Amanlou: Visualization, Investigation, Writing -original draft- review \& editing.

\section{Funding}

This research did not receive any specific funding.

\section{Data availability}

The data that support the findings of this study are available from the corresponding author upon request.

Code availability (software application or custom code)

Not applicable. 


\section{Ethics approval}

All procedures in the present work were approved by the Animal Care and Welfare Committee of the Department of Animal Sciences, Faculty of Agriculture and Natural Resources, University of Zanjan, Zanjan, Iran. The authors confirm that the ethical policies of the journal, as noted on the journal's author guidelines page, have been adhered to and the appropriate ethical review committee approval has been received. The authors confirm that they have followed EU standards for the protection of animals used for scientific purposes.

\section{Consent to participate}

Not applicable.

\section{Consent for publication}

Not applicable.

\section{Conflicts of interest}

The authors declare no conflicts of interest.

\section{References}

1. Allen, M.S., Bradford, B.J., and Harvatine, K.J., 2005. The cow as a model to study food intake regulation. Annual Review of Nutrition. 25, 523-547.

2. Balogh, O., Szepes, O., Kovacs, K., Kulcsar, M., Reiczigel, J., Alcazar, J., Keresztes, M., Febel, H., Bartyik, J., and Fekete, S.G., 2008. Interrelationships of growth hormone Alul polymorphism, insulin resistance, milk production and reproductive performance in Holstein-Friesian cows. Veterinární Medicína. 53, 604-616.

3. Bonczek, R., Young, C., Wheaton, J., and Miller, K., 1988. Responses of somatotropin, insulin, prolactin, and thyroxine to selection for milk yield in Holsteins. Journal of Dairy Science. 71, 24702479.

4. Butler, S.T., Marr, A., Pelton, S.H., Radcliff, R., Lucy, M.C., and Butler, W., 2003. Insulin restores GH responsiveness during lactation-induced negative energy balance in dairy cattle: effects on expression of IGF-I and GH receptor 1A. Journal of Endocrinology. 176, 205-2017.

5. Butler, W.R., 1998. Effect of protein nutrition on ovarian and uterine physiology in dairy cattle. Journal of Dairy Science. 81, 2533-2539.

6. Celi, P., and Gabai, G., 2015. Oxidant/antioxidant balance in animal nutrition and health: the role of protein oxidation. Frontiers in Veterinary Science. 2, 48.

7. Djoković, R., Dosković, V., Cincović, M., Belić, B., Fratrić, N., Jašović, B., and Lalović, M., 2017. Estimation of Insulin Resistance in Healthy and Ketotic Cows during an Intravenous Glucose 
Tolerance Test. Pakistan Veterinary Journal. 37.

8. Drackley, J.K., 1999. Biology of dairy cows during the transition period: The final frontier? Journal of Dairy Science. 82, 2259-2273.

9. Duffield, T., 2000. Subclinical ketosis in lactating dairy cattle. Veterinary Clinics of North America: Small Animal Practice. 16, 231-253.

10. Gheise, N.J.E., Riasi, A., Celi, P., and Shahneh, A.Z., 2018. Effects of dietary supplementation of pioglitazone or walnut meal on metabolic profiles and oxidative status in dairy cows with high precalving BCS. Journal of Dairy Research. 85, 16.

11. Ghoreishi, S. 2012. "Feeding of pioglitazone in ruminants and its effects on ruminal fermentation, some blood parameters, dry matter intake." PhD, Department of Animal Science, Isfahan University

12. Houseknecht, K.L., Cole, B.M., and Steele, P.J., 2002. Peroxisome proliferator-activated receptor gamma (PPARY) and its ligands: a review. Domestic Animal Endocrinology. 22, 1-23.

13. Ide, T., Nakazawa, T., Mochizuki, T., and Murakami, K., 2000. Tissue-specific actions of antidiabetic thiazolidinediones on the reduced fatty acid oxidation in skeletal muscle and liver of Zucker diabetic fatty rats. Metabolism. 49, 521-525.

14. Kadegowda, A., Bionaz, M., Piperova, L., Erdman, R., and Loor, J., 2009. Peroxisome proliferatoractivated receptor-y activation and long-chain fatty acids alter lipogenic gene networks in bovine mammary epithelial cells to various extents. Journal of Dairy Science. 92, 4276-4289.

15. Kerestes, M., Faigl, V., Kulcsár, M., Balogh, O., Földi, J., Fébel, H., Chilliard, Y., and Huszenicza, G., 2009. Periparturient insulin secretion and whole-body insulin responsiveness in dairy cows showing various forms of ketone pattern with or without puerperal metritis. Domestic Animal Endocrinology. $37,250-261$.

16. Kushibiki, S., Hodate, K., Shingu, H., Ueda, Y., Shinoda, M., Mori, Y., Itoh, T., and Yokomizo, Y., 2001. Insulin resistance induced in dairy steers by tumor necrosis factor alpha is partially reversed by 2,4thiazolidinedione. Domestic Animal Endocrinology. 21, 25-37.

17. Larsen, P.J., Jensen, P.B., Sørensen, R.V., Larsen, L.K., Vrang, N., Wulff, E.M., and Wassermann, K., 2003. Differential influences of peroxisome proliferator-activated receptorsy and-a on food intake and energy homeostasis. Diabetes. 52, 2249-2259.

18. Lucy, M. 2004. "Mechanisms linking the somatotropic axis with insulin: Lessons from the postpartum dairy cow." Proceedings of the New Zealand Society of Animal Production.

19. Mashek, D., Bertics, S., and Grummer, R., 2002. Metabolic fate of long-chain unsaturated fatty acids and their effects on palmitic acid metabolism and gluconeogenesis in bovine hepatocytes. Journal of Dairy Science. 85, 2283-2289.

20. NRC, I. 2001. Nutrient requirements of dairy cattle, National Research Council. Washington, D.C.: National Academies Press.

21. Ospina, P., Nydam, D., Stokol, T., and Overton, T., 2010. Associations of elevated nonesterified fatty acids and $\beta$-hydroxybutyrate concentrations with early lactation reproductive performance and milk 
production in transition dairy cattle in the northeastern United States. Journal of Dairy Science. 93, 1596-1603.

22. Pescara, J., Pires, J., and Grummer, R., 2010. Antilipolytic and lipolytic effects of administering free or ruminally protected nicotinic acid to feed-restricted Holstein cows. Journal of Dairy Science. 93, 5385-5396.

23. Pires, J., Souza, A., and Grummer, R., 2007. Induction of hyperlipidemia by intravenous infusion of tallow emulsion causes insulin resistance in Holstein cows. Journal of Dairy Science. 90, 27352744.

24. Revelo, X., and Waldron, M., 2010. Effects of in vitro insulin and 2, 4-thiazolidinedione on the function of neutrophils harvested from blood of cows in different physiological states. Journal of Dairy Science. 93, 3990-4005.

25. Rosa, F., Osorio, J.S., Trevisi, E., Yanqui-Rivera, F., Estill, C.T., and Bionaz, M., 2017. 2, 4Thiazolidinedione treatment improves the innate immune response in dairy goats with induced subclinical mastitis. PPAR Research. 2017.

26. Schoenberg, K., and Overton, T., 2011. Effects of plane of nutrition and 2, 4-thiazolidinedione on insulin responses and adipose tissue gene expression in dairy cattle during late gestation. Journal of Dairy Science. 94, 6021-6035.

27. Schoenberg, K., Perfield, K., Farney, J., Bradford, B., Boisclair, Y., and Overton, T., 2011. Effects of prepartum 2, 4-thiazolidinedione on insulin sensitivity, plasma concentrations of tumor necrosis factor-a and leptin, and adipose tissue gene expression. Journal of Dairy Science. 94, 5523-5532.

28. Smith, K., Butler, W., and Overton, T., 2009. Effects of prepartum 2, 4-thiazolidinedione on metabolism and performance in transition dairy cows. Journal of Dairy Science. 92, 3623-3633.

29. Smith, K., Stebulis, S., Waldron, M., and Overton, T., 2007. Prepartum 2, 4-thiazolidinedione alters metabolic dynamics and dry matter intake of dairy cows. Journal of Dairy Science. 90, 3660-3670.

30. Tordjman, J., Chauvet, G., Quette, J., Beale, E.G., Forest, C., and Antoine, B., 2003. Thiazolidinediones block fatty acid release by inducing glyceroneogenesis in fat cells. Journal of Biological Chemistry. 278, 18785-18790.

31. Wildman, E., Jones, G., Wagner, P., Boman, R., Troutt Jr, H., and Lesch, T., 1982. A dairy cow body condition scoring system and its relationship to selected production characteristics. Journal of Dairy Science. 65, 495-501.

32. Wolden-Hanson, T., Marck, B.T., and Matsumoto, A.M., 2002. Troglitazone treatment of aging Brown Norway rats improves food intake and weight gain after fasting without increasing hypothalamic NPY gene expression. Experimental Gerontology. 37, 679-691.

33. Yousefi, A., Kohram, H., Zare Shahneh, A., Zamiri, M., Ghaziani, F., Kazemi Khoozani, M., Ghoreishi, S., and Arab, H., 2015. Plasma pharmacokinetics of pioglitazone following oral or intravenous administration in Holstein cows. Archives of Razi Institute. 70, 97-104.

34. Yousefi, A.R., Kohram, H., Shahneh, A.Z., Zamiri, M.J., Dirandeh, E., Khoozani, M.K., Davachi, N.D., Zhandi, M., and Folladi-Nashta, A.A., 2019. Effect of oral administration of pioglitazone on follicular 
dynamics in Holstein dairy cows. Livestock Science. 224, 50-56.

35. Yousefi, A.R., Kohram, H., Shahneh, A.Z., Zamiri, M.J., and Fouladi-Nashta, A.A., 2016. Effects of dietary supplementation of pioglitazone on metabolism, milk yield, and reproductive performance in transition dairy cows. Theriogenology. $85,1540-1548$.

\section{Figures}

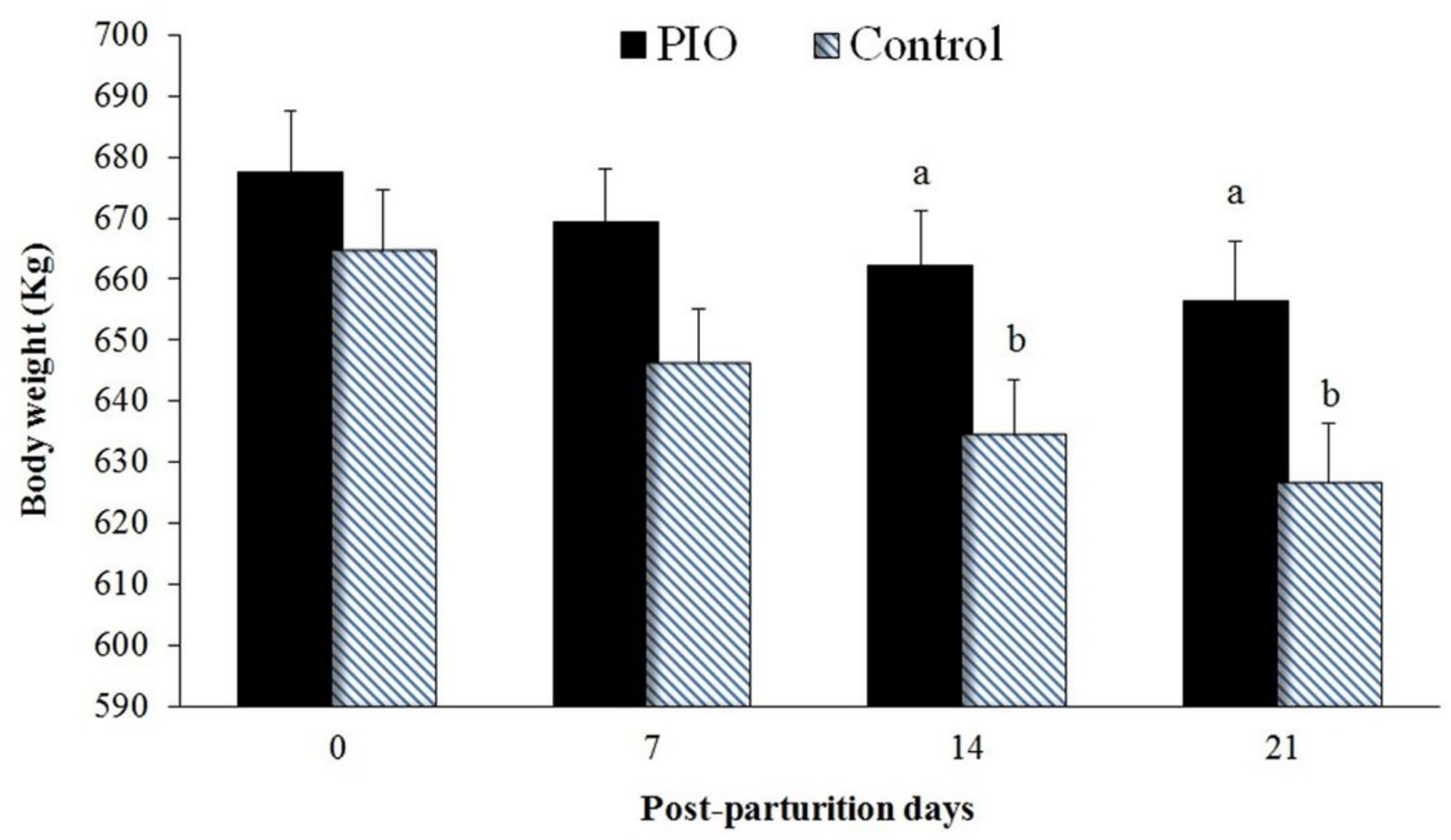

Figure 1

The effect of pioglitazone on body weight in Holstein dairy cows during the postpartum period.

Note: Within each time point, values with different superscripts $(a, b)$ are significantly different $(P<0.05)$. 


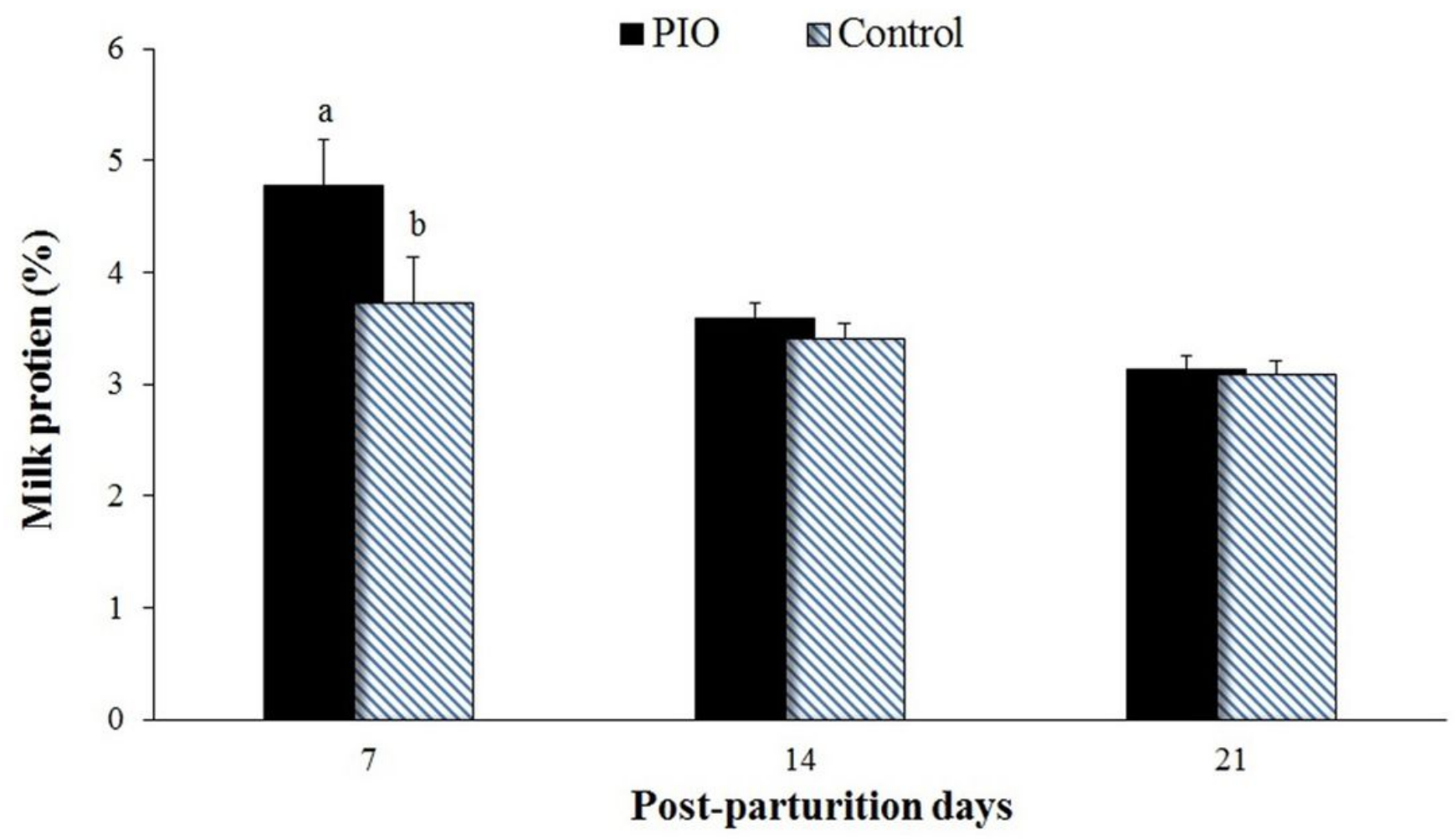

Figure 2

Effect of pioglitazone on milk protein percentage in Holstein dairy cows during postpartum period.

Note: Within each time point, values with different superscripts $(a, b)$ are significantly different $(P<0.05)$. 


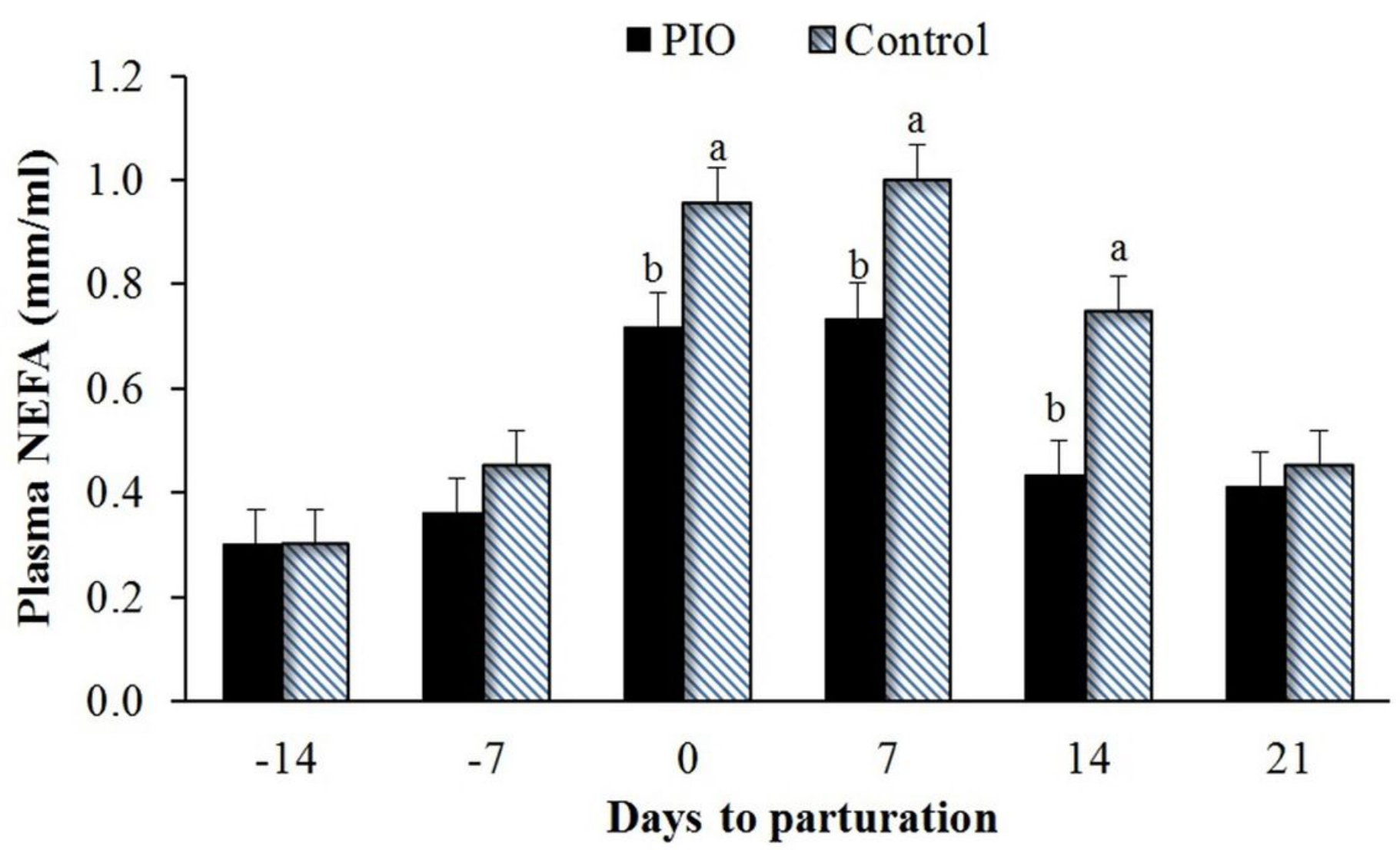

Figure 3

Effect of pioglitazone on plasma NEFA concentration in Holstein dairy cows during transition period.

Note: Within each time point, values with different superscripts $(a, b)$ are significantly different $(P<0.05)$. 


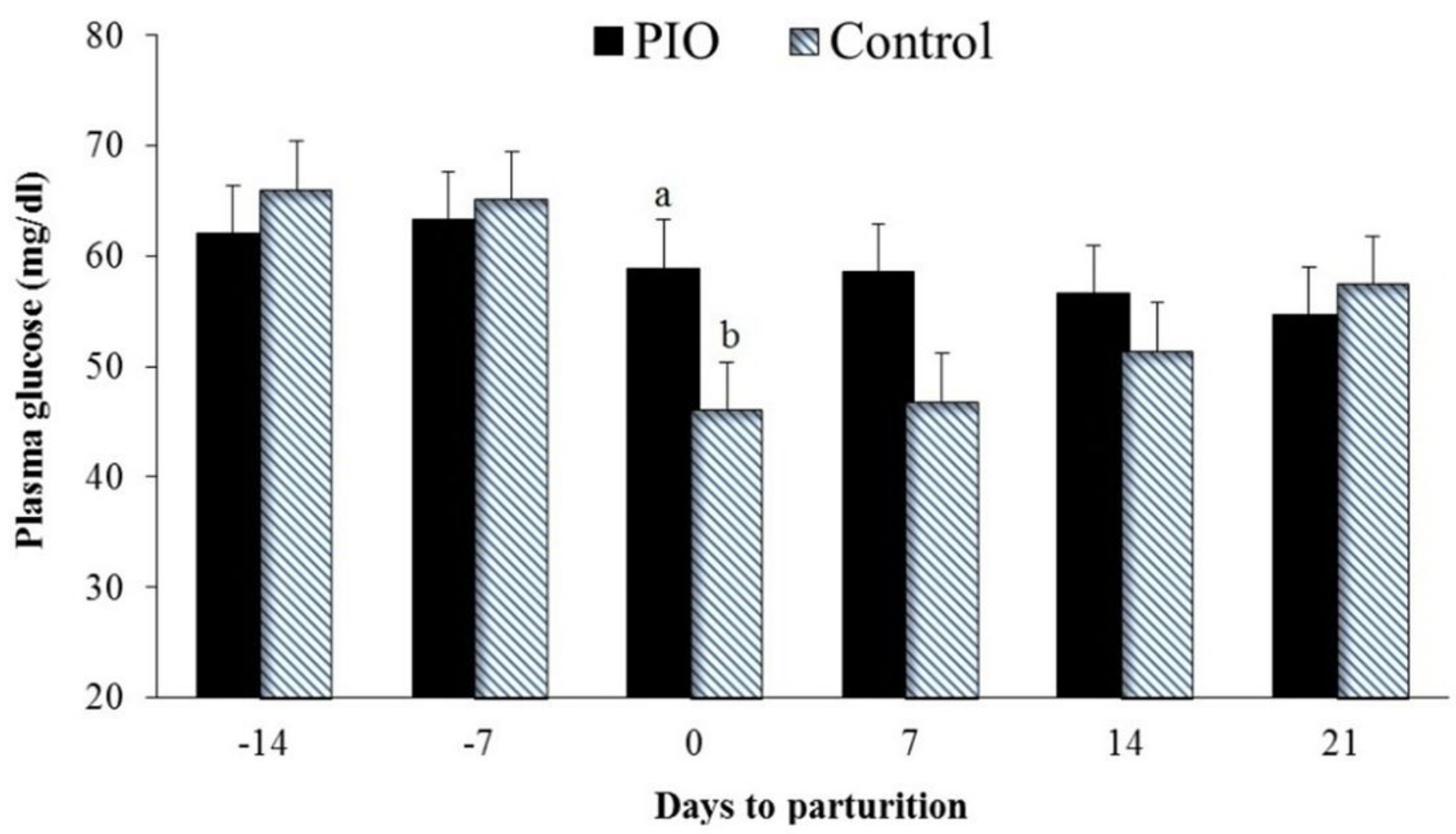

Figure 4

Effect of Pioglitazone on plasma glucose concentration in Holstein dairy cows during transition period. Note: Within each time point, values with different superscripts $(a, b)$ are significantly different $(P<0.05)$. 


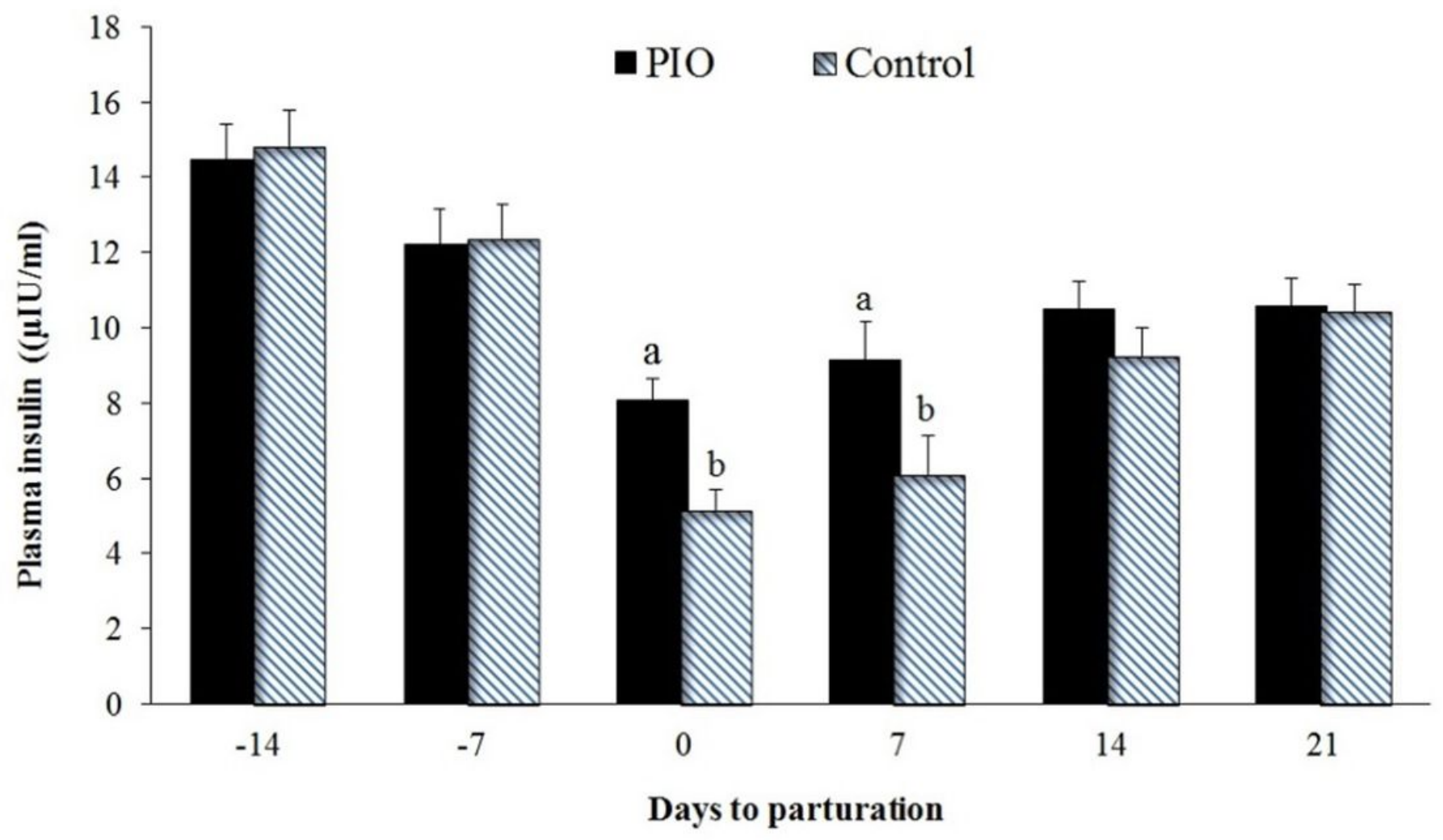

Figure 5

Effect of Pioglitazone on plasma insulin concentration in Holstein dairy cows during transition period.

Note: within each time point, values with different superscripts $(a, b)$ are significantly different $(P<0.05)$. 


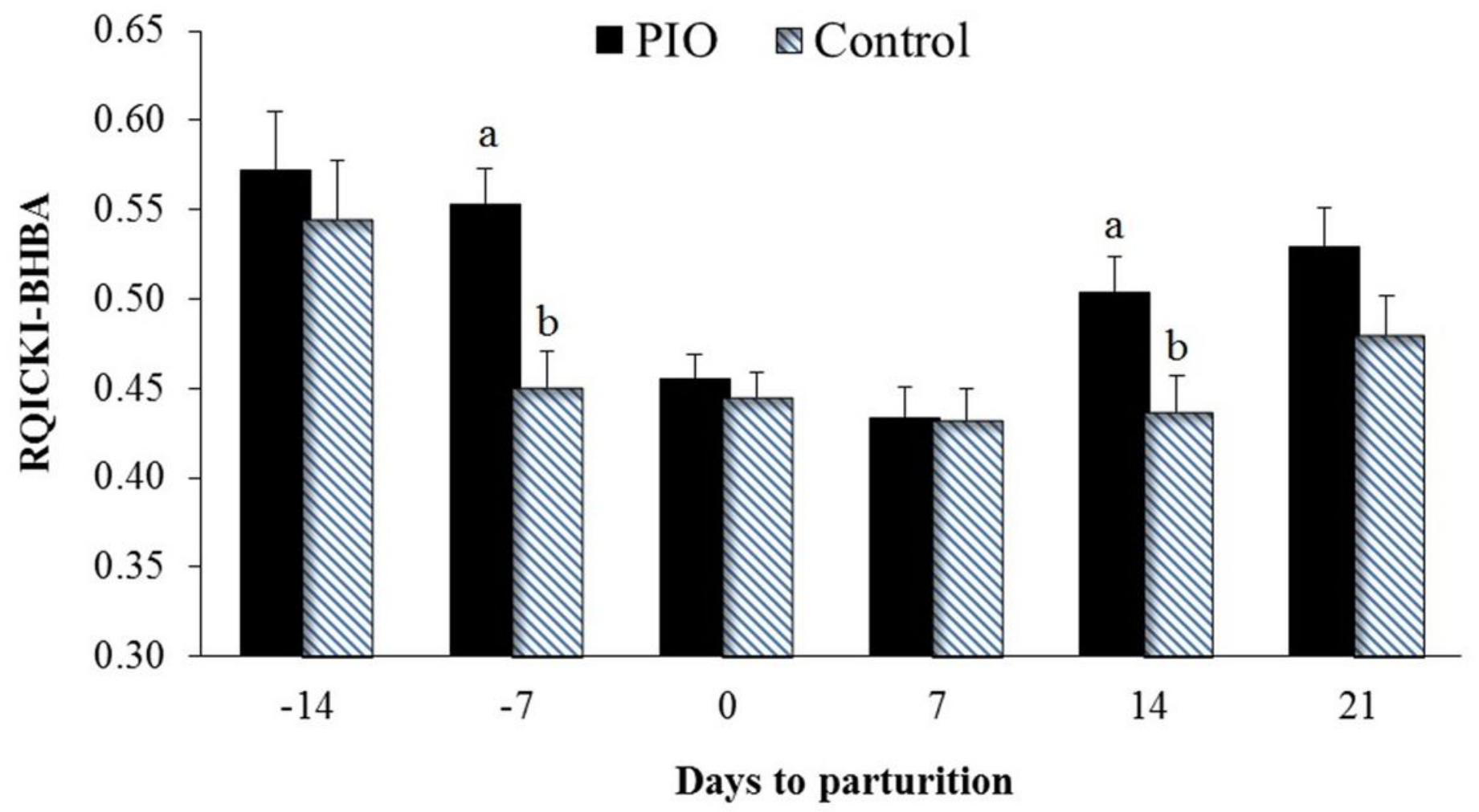

Figure 6

Effect of Pioglitazone on RQICKI-BHBA index in Holstein dairy cows during transition period.

Note: Within each time point, values with different superscripts $(a, b)$ are significantly different $(P<0.5)$ 